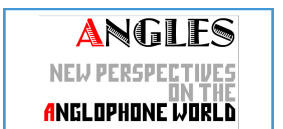

ANELOPHONE WORLD

\section{Angles}

New Perspectives on the Anglophone World

13 | 2021

The Torn Object

\title{
Getting it All Down: Disintegration and Integration in B. S. Johnson's The Unfortunates
}

\section{Ben Winsworth}

\section{(2) OpenEdition}

12 Journals

Electronic version

URL: https://journals.openedition.org/angles/4322

DOI: 10.4000/angles.4322

ISSN: 2274-2042

\section{Publisher}

Société des Anglicistes de l'Enseignement Supérieur

Printed version

Date of publication: 15 December 2021

\section{Electronic reference}

Ben Winsworth, "Getting it All Down: Disintegration and Integration in B. S. Johnson's The

Unfortunates", Angles [Online], 13 | 2021, Online since 15 December 2021, connection on 29 December 2021. URL: http://journals.openedition.org/angles/4322 ; DOI: https://doi.org/10.4000/angles.4322

This text was automatically generated on 29 December 2021.

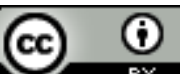

Angles est mise à disposition selon les termes de la Licence Creative Commons Attribution 4.0 International. 


\title{
Getting it All Down: Disintegration and Integration in B. S. Johnson's The Unfortunates
}

\author{
Ben Winsworth
}

1 The Unfortunates, first published in 1969 , is B. S. Johnson's most infamous novel, the celebrated book in a box comprising twenty-seven loose, unbound single pages and printer's signatures that - apart from one marked "First" and another one "Last" can be read in any order that the reader is invited to shuffle the text into. ${ }^{1}$ A novel dismissed as small-scale by many contemporary reviewers: a disposable "Kleenex novel" (Herbert 1969), a "paper-chase game" (Holmes 1969) or "record-set" (Pacey 1972), and one described on its republication in 1999 as a "splendid oddity" (Hitchings 1999) and "an experiment that proves to be empty" (Arditti 1999). ${ }^{2}$ Clearly there is a sense in which the format of The Unfortunates is a gimmick, a typical Johnsonesque pose, yet this is not so surprising in the work of a writer whose first novel, Travelling People (1963), borrowed devices from Laurence Sterne's Tristram Shandy, and who was to write, when acknowledging that debt, that "it was necessary to return to the very beginnings of the novel in England in order to try and re-think it and re-justify it for myself" (Johnson 1973: 21). In The Unfortunates, the process of rethinking is taken a step further when the spirit of Tristram Shandy appears not simply in the narrative telling and non-telling, but in the self-conscious playing with the physical form and mechanics of the book as an object to be manually, as well as visually and intellectually, apprehended (Figure 1). It is, as Johnson has suggested in the introduction to Aren't You Rather Too Young to be Writing Your Memoirs?, "a physical metaphor for randomness" (1973: 25), most significantly the randomness that is cancer, and it is the deliberate deconstruction of the conventionally bound novel that allows the tangible text to reflect the chaotic and painful subject matter dealt with inside the box that also contains it. 
Figure 1: Picture of opened box with B.S. Johnson's The Unfortunates (from the 1999 Picador edition)

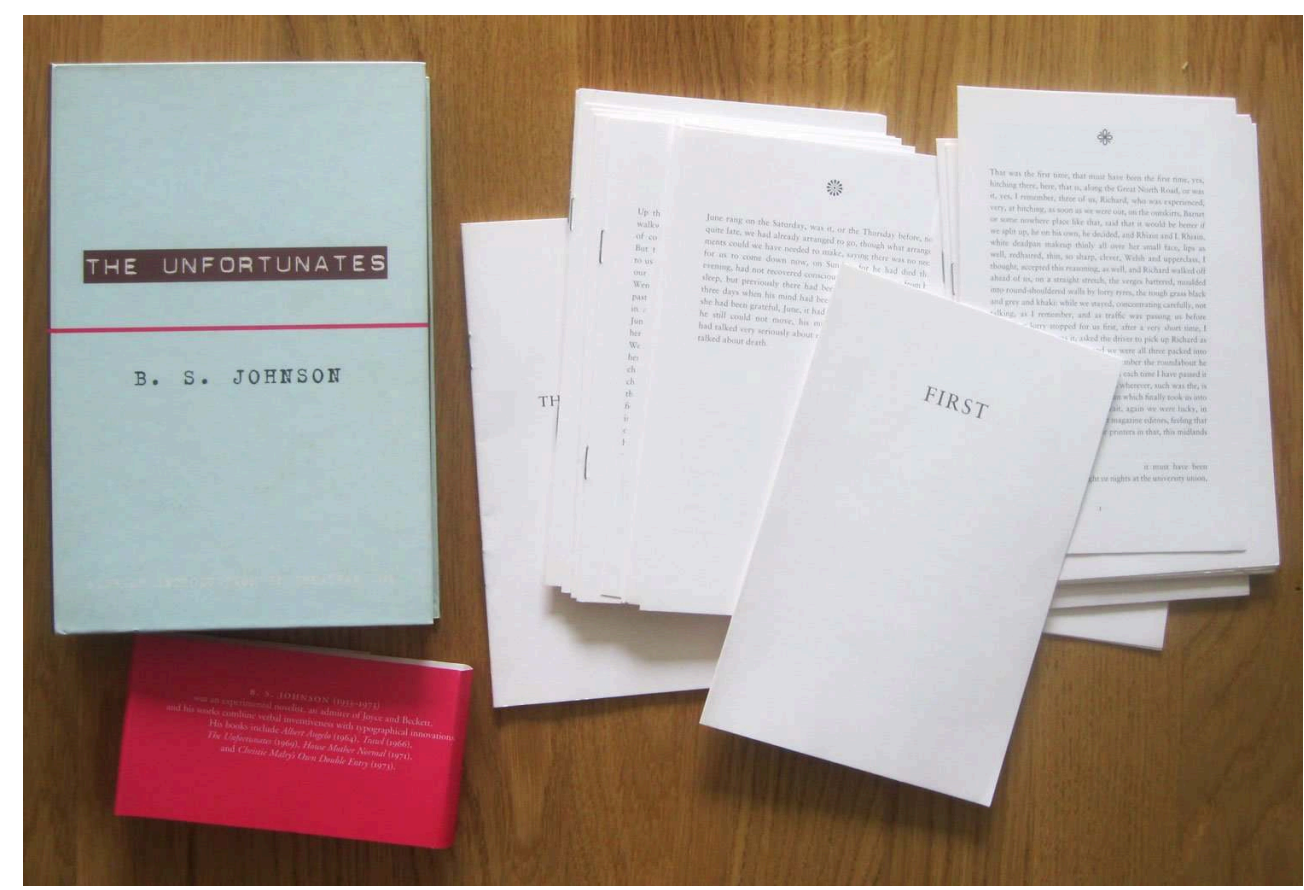

Richard Littler: " B. S. Johnson's The Unfortunates (1969). His 'book in a box' contained 27 unbound chapters with only the first and last specified."

Credits: https://twitter.com/richard_littler/status/1012602572446883841

2 Johnson's ardent vocation to reanimate what he believed to be a genre in terminal decline, led him to make many apparently controversial statements that were, until even fairly recently, regarded sceptically by reviewers and critics. His grumbling about the logical impossibility of conveying truth in a "vehicle of fiction"; his proud boast about not being interested in "telling lies in my own novels"; and his insistence that the novelist's allegiance to truth is justified because life itself does not tell stories (1973: 14), have resulted in him sometimes being labelled as an anti-novelist pedalling an "extraordinarily perverse credo" (Arditti 1999). Perverse it may at first appear, but if we look momentarily beyond Johnson's place within the context of the avant-garde of British fiction and the work of contemporaries like Eva Figes, Alan Burns, Ann Quin and Christine Brooke-Rose, we come closer to understanding where he is coming from and attempting to go to: "The novel is a form in the same sense that the sonnet is a form; within that form, one may write truth or fiction. I choose to write truth in the form of a novel" (1973: 14). An unblinkingly straightforward statement expressing a dogged fidelity to the truth that is almost paradoxical in a writer who, like many of the experimental writers associated with him, rejected the social realism of the post-war novel. However, Johnson understood the truth to be not only the raw material of his own life, but something that manifested itself within the avant-garde's mistrust of the teleological narrative - better supplied, so he believed, by film and TV - and its attempt to recreate the arbitrary nature of existence through a radical rearrangement of form. It is that difficult and complex commitment to the idea of truth, and Johnson's struggle to harness it, that informs his own idiosyncratic take on the novel and also marks him out as having a different agenda to postmodern writers of the period like John Fowles. 
The Unfortunates tries to excel in two particular areas that Johnson believed would allow the novel as a genre to survive and triumph: "exploitation of the technological fact of the book and the explication of thought" (1973: 12). However, his continual insistence on the not fictionalising of experience, a paradoxical position for a writer also keen to state that he writes novels and not works of non-fiction, has often placed him in an awkward position and drawn more attention to the box of tricks aspect to The Unfortunates rather than to the painful tales recounted within it. ${ }^{3}$ In many ways the "exploitation of the technological fact of the book" was received superficially as exploitation for its own sake by the literary establishment, and the fact that Johnson's novels quickly fell into the out-of-print graveyard after his death seemed to confirm a general belief that here was a literary charlatan who had got it badly wrong. Looking back more sympathetically to the anti-establishment zeitgeist of the 1960 s and the engaged and committed nature of its cultural productions, we can understand Johnson's complex and sometimes contradictory artistic manifesto to be driven by a desire to reject fictional forms that flatter and/or invite escape. The Unfortunates, while it is at once a creative, playful, and imaginatively conceived novel, is also one that attempts to address reality as directly as possible in form and content: a task that is both difficult and disconcerting. It is the disconcerting content of the text, rather than its experimental quality, that Jonathan Coe understands to have been responsible for the novel being relegated to the margins of the literary establishment. In his introduction to the 1999 Picador edition of The Unfortunates, he states:

If Johnson's peers never quite gave his novels the recognition they deserved, it was because they presented an emotional challenge, rather than a formal one. Militantly working class, with no access to the Oxbridge network and a nasty habit - through his union connections - of dirtying his hands with the messy business of political activism, Johnson was, in many ways, an embarrassment to the literary establishment. The feeling in his books was too raw, too upfront. They lacked the veneer of politeness and diffidence which England always admired in its writers. (xiv)

4 Times may have changed somewhat and the influence of trauma studies in the 1990s may have created a more sympathetic theoretical approach and context in which to accommodate the painful subject matter that Johnson brings forth, but the "graphic literalness of description" and "raw emotional honesty" noted by Philip Tew (2001: 41) still makes it difficult to grapple with, if not more so than the manner in which the novel is (un)structured.

5 In an accompanying letter sent to his publishers with his new and innovative manuscript, Johnson wrote of his belief that the novel "reflects the random way in which past and present interact in the mind: it is an enactment of randomness which the bound book simply cannot achieve" (Coe 2004: 237-8). Certainly the random nature in which we are invited to read the main body of the text reflects the thought processes of the narrator/B. S. Johnson as he shuttles between his present task of watching and reporting a football match in the city in which an important and valuable friendship crystallised. That friend - simply "Tony" in the novel, Tony Tillinghast in real life died of cancer in 1964 and The Unfortunates is in many ways Johnson's attempt to fulfil a promise made to his dying friend, a promise 'quoted' within one of the novel's sections: "I'll get it all down, mate" ('So he came to his parents', 5). ${ }^{4}$

6 Getting it all down, or rather how to get it all down is the novel's primary concern and/ or problem. As the fragmentary nature of the book expresses the disintegration and 
physical breakdown of Tony's body, as well as the random nature of cancer in terms of its metastasis and development, ${ }^{5}$ it also signals the emotional and technical difficulties inherent in both remembering and writing that plague the body of the narrative itself, in whatever order or different orders we choose to read it. The narrator's interior monologues that alternate haphazardly between the concerns and reflections of his present situation, and the memories that are activated as a consequence of the contexts in which he finds himself, anticipate, parallel, and self-consciously reveal the very act of writing The Unfortunates. In other words, the book becomes an extension of the earlier struggle to remember and understand: "I cannot think, it is so difficult... I fail to remember, the mind has fuses..." ('Then he had moved', 4-5); "all memories are curious, for that matter, the mind as think of an image

( 'The estate', 5). As the memory fails in recollecting the past - "do I impose this in the knowledge of what happened later? A constant, ha, distorting process, what is true about the past...?" ('Up there, yes', 2) - so the written text with its gaps, pauses, unfinished sentences, syntactical uncertainties, and self-questioning, paradoxically recreates the truth of experiencing experience. It also echoes the concerned and pessimistic tone of the words spoken between the two friends after the narrator's final promise to write everything down: "It'll be very little, he said, after a while, slowly, still those eyes. That's all anyone has done, very little, I said" ('So he came to his parents', 3).

7 Johnson's reply to Tony's dismissive comment about the lack of substance in his life, a reply that confirms the desperate realism or gallows humour of his friend, in some senses anticipates the negative criticism of The Unfortunates as not being about, or indeed saying, very much. Reading the novel more closely, however, reveals that Johnson in saying very little actually says a lot, something that is amplified, paradoxically, through the textual silences that reflect the stark reality of Tony's death at the same time as they acknowledge the difficulty and/or impossibility of getting it all down. ${ }^{6}$ In whatever order the novel is read, the passages detailing the physical decline of Tony appear, chorus-like, with frequent and painful reality, and the unblinking honesty of the descriptions creates a fixed focal point that both contains and contrasts with the surrounding narrative chaos:

Just in the few weeks since we had last seen him he was grossly altered, distressingly, his face had shrunken, lost much of its flabbiness, rotundness, life, the skin was now tighter so that it was shocking, yes, to recognise him, now, from what he had been, then. This diminution made his features stand out more, which were not that noticeable before, his eyes stood out, stared, fixed you [...] now the mouth was not fleshy, the flesh was gone, not gone, but tautened, disfigured, and the teeth were there, their roots showing [...] his skin too was yellow [...] and now he really looked like a man who had undergone months of pain, fear, to me [...] ('So he came to his parents', 2)

Such descriptions, together with passages recalling the history of Tony's illness, are moving, not in a sentimental manner, but in their realistic presentation of something that is at once painful, pitiful, pathetic, and yet so commonplace. The overall effect is similar to Auden's observation in 'Musée des Beaux Arts' that suffering takes place while "someone else is eating or opening a window or just walking dully along" (Auden 1979: 79), its almost trivial status giving it more weight as it draws attention to the absurd nature of human experience. Johnson's attempt to get it all down is even more commendable in the historical context of the novel's publication when, in comparison with today's slightly more up front and open attitude, cancer was still something of a 
taboo subject. The disintegration of Tony's sickening body, transformed by Johnson into a memento mori-like presence, manifests itself not only in the fragmentation of the narrative, but also in the havoc it wreaks on other peoples' lives. The temporary highs and depressing lows of remission and regression; the moments of denial followed by painful attempts by Tony and his wife to come to terms with serious illness; Tony's father's bitter outcry: "Can you understand it, can you understand why his mother had to go through such pain bearing him, only for this to happen now?" ('So he came to his parents', 1); the presence of Tony's young son playing innocently outside while his father is dying, a small, but powerful detail highlighting the fragility of existence, of another life about to be shattered by this death; are all recorded by Johnson, as is his own pain and terror, intensified through re-experiencing it in the process of writing. ${ }^{7}$

That process is troubled by an almost obsessive agony running through the novel about not being able to write about these things - to get it all down - as if Johnson is in some senses challenged by his own creed of truth-telling. Once again it is the acknowledgement of failures in this area that makes the attempt a success: those moments of break down, of silence, the white spaces in the narrative, which also illustrate the difficulty of Johnson's task as he tries to fill the emptiness left by the absence of his friend. ${ }^{8}$ In one passage Johnson notes that Tony and June have bought a tape-recorder and how Tony said they "recorded conversations, tried to write things as well, poems, against this unwelcome shortfall" ('So he came to his parents', 3). Johnson too, interviews Tony on his own recorder in the process of trying to gather material for an article on the ill effects of urban planning, and he worries, in recalling this, whether there was a more ghoulish motive behind it. He concludes:

[...] but not now, no, I have the man's voice still, the shake in it that was not there before, the sippings, the pauses, long sighs, I remember so clearly, have played it enough times, his voice, or the last vestiges of it, it's not that clear, a new slur, too, but his voice, his voice I still have, yes, and what he said, what he was. ('Then they had moved', 7)

10 This concern with recording, with possession - "his voice I still have" - mirrors the attempt to record the experience in the novel. The "sippings, the pauses, long sighs" of Tony's voice all find their textual equivalent in the written narrative, but they can never fully recreate the experience as it happened, nor can they fully compensate for Tony's death. Johnson may "have" Tony's voice, but it is a disembodied voice that only works to emphasise the death of the speaker. While recording, either on tape or on paper, is a gesture "against this unwelcome shortfall" the attempt will always fall short. Johnson is aware of this, but at the same time has enough of a belief in the power of language and the novel to push ahead and try to do the best he can, which for Johnson means radically altering the structure and physical form of his chosen medium. ${ }^{9}$

11 Much critical attention has been focused on the unbound sections of The Unfortunates, but just as important is the box that contains them and provides the framework. Even if we can physically take out the pages and sections, most readers probably have the box close to hand during their own readings and, I suspect, return the pages to the box when reading is temporarily suspended. The 'empty' box itself has B. S. Johnson's report of the football match pasted within it, printed instructions on how to approach the reading of the novel, and three quotations: one from Laurence Sterne and two from Samuel Johnson. Each of these texts points towards the thematic or experimental concerns of the novel and invites further readerly participation in an activity that establishes a close relationship between the box and its contents. In so doing it is 
possible to suggest that Johnson is deliberately drawing self-conscious attention to the box as the only place (or space) in which the random nature of his narrative can have any real significance. Paradoxically, the box is that which the novel resists and that which the novel needs, almost as if one of the experimental directives in the conception of The Unfortunates required taking the form of the novel to pieces to see how it worked, examining its physical contents and emptied carcass, only to put it back together again with a renewed knowledge of its strength and weakness as a genre. This too is what Johnson means when he talks about the need to go back to the origins of the English novel to re-think and re-justify it for himself.

Traditional narrative ordering can be abandoned, but such experimental techniques as we find in The Unfortunates require, to use D. W. Winnicott's conception of infant play, the "holding environment" of the book as a physical, intellectual and emotional container that facilitates a movement towards integration (Winnicott 1965). Without the provision of a good enough holding environment in early infancy, with the absence of any ego boundary, infant playing becomes too instinctual, too chaotic, has little meaning, and fails to contribute to the creative development of the individual. Winnicott conceives of the holding environment as being non-invasive in its 'supervision' of the playing area, but none the less necessary in providing - like Johnson's box and the "technological fact of the book" that it brings into the foreground of our reading experience - a safeguard against complete disintegration. It is the box that allows the trauma, as well as the experimental manner in which that trauma is relayed, to be experienced in a safe space, paradoxically allowing for language, form and structure to fall apart and yet be held together and tolerated. In the same way as Johnsons's tenacious hanging onto the idea of truth gives him the confidence needed to exercise his experimental manifesto, so the framing of the box offers emotional and physical reassurance in connecting the disconnected words, signatures and thoughts, harbouring them in a place where they can be given meaning or at least mean something, both for Johnson and the reader.

Many metafictional parallels have been made between the narrator's/B. S. Johnson's reporting on the City v United football match and the structure of The Unfortunates. Football, in being a game played to a certain set of rules within a defined period of space and time, but one that within such a framework allows for all sorts of random variations in terms of individual and collective performances, is an apt mise en abyme. In the light of this it is important to take note of the narrator's description of the excitement and expectation that builds up towards the three o'clock kick off:

Always at the start of each match, the excitement, often the only moment of excitement, that this might be the ONE match [...] where the extraordinary happens, something that makes it stand out, the match one remembers and talks about for years afterwards, the rest of one's life. The one moment, the one match. A new beginning is it? ('The pitch worn', 1)

14 Probably not, as it soon becomes apparent that the present match is, like so many others, going to quickly descend into a long drawn out and overwhelmingly dull confrontation. On another level this can be read as a modest reflection upon the virtues (and limitations) of The Unfortunates as an experimental novel. At first the narrator's expectations share something of the excitement inherent in both Johnson's conception of the novel and the reader's reception of it as he or she opens the virgin box and removes the paper sleeve temporarily holding the unbound pages and signatures together. Could this be the one moment, the one book, a new beginning? The exercise 
in randomness is, as some critics have noted, undermined by the fact that it doesn't really matter how the reader arranges the order of the novel's sections or how many times and different ways it is read. The same bleak results are endlessly replayed: Tony still dies of cancer and City still beat United one nil. There are no hidden surprises to be found in the book, but looking for them is to misunderstand a project that, while attempting to establish the random nature of real experience through both form and subject matter, is also acknowledging a powerful current of inevitability in death, the final whistle, or the end of the novel. The narrative of life itself is random in between its first and final parts, but ultimately, as The Unfortunates so doggedly insists, we are all heading towards the closed box of our own lives. In many ways the 'book in the box' is mere packaging, a publicity stunt, and while it functions as a metaphor for "the randomness that is the nature of cancer" it must fail if Johnson's attempt to translate something of the reality of life is to succeed. Randomness in terms of offering a choice of endings, as in John Fowles' The French Lieutenant's Woman, also published in 1969, would only be to fictionalise reality, to tell lies primarily because Tony, like most of us, has no choice about his own ending.

From its first appearance the experimental aspect of the novel has also been criticised for being too whimsical to contain the painful subject matter of terminal illness (Parrinder 1977) or, conversely, that the banal subject matter does not match up to the avant-garde aspirations of its form (Davies 1985). This, however, is to miss the point of the exercise. There is something dull and depressing about the narrator's observations beyond the understandable and obsessive attempt to accommodate Tony's death, almost as if the lives contained within the box are playing out their own disjointed and disappointing football match with Samuel Beckett as the glum referee. Here too the novel fails to live up to its promise, not that it really promises anything in terms of its content, and this can be viewed as another disappointment that paradoxically contributes to the success of the exercise: one that reflects back upon the unavoidable failure of the random structure in a positive light. Ultimately, The Unfortunates is a deliberate and inevitably flawed attempt to capture something of the essence of human experience and the random ordinariness and dull predictability of existence. In so being it challenges us, like many of Johnson's controversial statements about the opposition between truth and fiction, to think about the nature of books - how we receive them, what we expect from them, what we do with them, how and in what order we read them - just as much as it is Johnson's personal manifesto about the need to keep on trying to tell it like it is.

\section{BIBLIOGRAPHY}

Arditti, Michael. “A House of Cards.” The Independent, 16 October 1999.

Auden, W. H. Selected Poems. London: Faber, 1979.

Davies, John. "The Book as Metaphor: Artifice and Experiment in the Novels of B. S. Johnson."

Review of Contemporary Fiction 5.2 (1985): 72-6. 
Coe, Jonathan. "Introduction to The Unfortunates." London: Picador, (1999): v-xv.

Coe, Jonathan. Like a Fiery Elephant: The Story of B. S. Johnson. London: Picador, 2004.

Fowles, John. The French Lieutenant's Woman. London: Jonathan Cape, 1969.

Guignery, Vanessa. Ceci n'est pas une fiction: Les romains vrais de B. S. Johnson. Paris: Sorbonne Université Presses, 2009.

Guignery, Vanessa. “B. S. Johnson's The Unfortunates: Revisiting the Elegy. ” Etudes Britanniques Contemporaines 41 (2011): 119-134. DOI : 10.4000/ebc.2353

Herbert, Hugh. “The Man Inside the Box.” The Guardian, March 151969.

Hitchings, Henry. “Back in Print.” New Statesman, November 81999.

Holmes, Richard. “Leaves in the Wind.” The Times, March 151969.

Hodgson, Andrew. The Post-War Experimental Novel: British and French Fiction, 1945-75. London: Bloomsbury, 2020.

Johnson, B. S. The Unfortunates. London: Picador, [1969] 1999.

Johnson, B. S. Aren't You Rather Too Young to be Writing Your Memoirs? London: Jordan, Hutchinson, 1973.

Julia. "For recuperation: elegy, form and the aleatory in B. S. Johnson's The Unfortunates." Textual Practice 28.5 (2014): 745-761. DOI: 10.1080/0950236X.2014.925495

Jordan, Julia, and Martin Ryle, eds. Avant Garde Possibilities: B. S. Johnson and the Sixties Generation. London: Palgrave Macmillan, 2014.

Lea, Daniel. "Narrative Wreckage: Cancer and the Unfortunate Body in B. S. Johnson." English Studies 96.7 (2015): 785-798. DOI: 10.1080/0013838X.2015.1051869

Mitchell, Kaye. "The Unfortunates: Hypertext, Linearity and the Act of Reading." In Re-reading B. S. Johnson. Eds. Philip Tew and Glyn White. Basingstoke: Palgrave Macmillan, 2007. 51-64.

Pacey, Philip. “Merely Human - The Writings of B.S. Johnson.” Stand 13.2 (1972): 61-4.

Parrinder, Patrick. “Pilgrim's Progress: The Novels of B. S. Johnson (1933-73)." Critical Quarterly

19.2 (Summer 1977): 45-59.

Tew, Philip. B. S. Johnson A Critical Reading. Manchester: Manchester UP, 2001.

Tew, Philip, and Glyn White, eds. Re-reading B. S. Johnson, Basingstoke: Palgrave Macmillan, 2007.

Winnicott, D. W. "Ego Integration in Child Development." The Maturational Processes and the Facilitating Environment. London: Karnac, [1965] 1990.

\section{NOTES}

1. It has been noted by several Johnson critics that this was an innovation most probably inspired by Marc Saporta's Composition No. 1 (1961).

2. Johnson was also largely ignored until fairly recently by academic criticism, a state of affairs that has been remedied by the work of Philip Tew and Glyn White (2007); Vanessa Guignery (2009); Julia Jordan and Martin Ryle (2014); and Andrew Hodgson (2020), for example.

3. Daniel Lea (2015) attempts to redress this balance, so too Vanessa Guignery (2011) when she suggests that Johnson's experimentation "does not preclude emotions but, on the contrary, often provides an original means of problematising the emotional and ethical dimension of writing, 
while at the same time refusing to give way to either pathos, sentimentality or consolation" (120).

4. Due to the lack of any conventional chapter or page numbering in The Unfortunates, the citations in parentheses refer to the opening phrase of the loose chapter in which the quotation is found and the numbers to the corresponding page within that chapter.

5. See Zulfikar Ghose qtd in Coe (2004) in which he recollects Johnson telling him that The Unfortunates was "based on randomness, because that was the nature of cancer" (230).

6. Julia Jordan (2014) offers reflections on the difficult yet vital task of "getting it all down".

7. Vanessa Guignery (2011) comments on this aspect of the novel and the ways in which Johnson works to engage the reader in an emotionally and ethically challenging experience.

8. Andrew Hodgson (2020) refers to the ambivalence of what he calls the "communicating absence" in the style of The Unfortunates (133) and the underlying anxiety about making sense that haunts the novel. He also feels that there is an interesting tension at work between the desire for revelation and concealment which seems to me to add to the 'verité' of the experience.

9. Kaye Mitchell comments on the ambivalence at work between the impossible attempt to order, construct and sequence events and yet the strange - one might add, understandable - comfort that such an enterprise offers as an act of deferral. (Tew and White 2007: 51-64)

\section{ABSTRACTS}

B. S. Johnson's infamous 'book in a box' The Unfortunates (1969) is more than an experiment in form. The unbound signatures of the novel we are invited to shuffle into any order before reading are not only expressive of Johnson's belief in the random nature of existence, but more specifically, as his friend Zulfikar Ghose noted, the randomness that is in the nature of cancer. The box of tricks aspect to the novel has often occluded the human story contained within it: the death of the narrator's/Johnson's friend Tony from cancer, and his attempt to fulfil his final promise to 'get it all down mate' and so write with unflinching honesty about the experience and its aftermath. Critics have either tended to dismiss the story of the lives contained within The Unfortunates as mundane and boring, or as failing to match up to the radical format of the text. However, in this article I will be reconsidering the relationship between form and content, arguing that the narrator's melancholy observation of life and descriptions of the slow and painful death of his friend are more than an adequate match for the structure/non-structure of the novel. Tony's physical disintegration and the narrator's depressive state of mind, as he reflects back upon the death of his friend and its consequences, find an ideal habitat in the fragmentary nature of The Unfortunates. I will also be attempting to show how the more formal, physical aspects of the novel - the box, the first and final part, the unnumbered signatures facilitate the dynamics of grief in providing a space for Johnson's interior monologues to take whatever experimental shape and direction they choose, while also working to hold and contain the emotional and intellectual conflicts within them and thus guard against complete disintegration. I shall be arguing that within this particular interplay there is a movement towards integration that, while it doesn't give Johnson any wholly positive insights, is at the very least a gesture towards the therapeutic for both himself and the reader.

Le fameux «livre dans une boîte » de B. S. Johnson, The Unfortunates (1969), est plus qu'une expérience formelle. Les feuillets non reliés du roman, que nous sommes invités à mélanger dans 
n'importe quel ordre avant de le lire, expriment non seulement la croyance de Johnson dans la nature accidentelle de la vie, mais reflètent plus particulièrement, comme l'a noté son ami Zulfikar Ghose, le caractère arbitraire du cancer. Le côté « boîte à malices » du roman a souvent occulté l'histoire humaine qu'il contient : la mort de Tony, l'ami du narrateur/B.S. Johnson, des suites d'un cancer, et la tentative de ce dernier de tenir sa promesse finale de «tout écrire, mon pote », de rapporter avec une honnêteté sans faille cette expérience et ses conséquences. Les critiques ont eu tendance à rejeter l'histoire des vies racontées dans The Unfortunates comme étant banale et ennuyeuse, ou à estimer qu'elle ne correspond pas à la forme expérimentale du texte. Cependant, dans cet article, je me propose de reconsidérer la relation entre la forme et le contenu, en arguant que l'observation mélancolique de la vie par le narrateur et les descriptions de la mort lente et douloureuse de son ami correspondent tout à fait à la structure/non-structure du roman. La désintégration physique de Tony et l'état d'esprit dépressif du narrateur, qui repense à la mort de son ami et à ses conséquences, trouvent un cadre idéal dans la nature fragmentaire de The Unfortunates. J'essaierai également de montrer comment les aspects plus formels et physiques du roman, notamment la boîte, la première et la dernière partie, les feuillets non numérotées, facilitent la dynamique du deuil en offrant un espace aux monologues intérieurs de Johnson pour qu'ils prennent la forme et la tournure expérimentales qu'ils souhaitent, tout en s'efforçant de retenir et de contenir les conflits émotionnels et intellectuels qu'ils renferment. De la sorte, l'expérience évite une désintégration complète. Dans cette interaction particulière, il y a un mouvement vers l'intégration qui, même s'il ne donne pas à Johnson des idées entièrement constructives, est à tout le moins un geste vers une forme la guérison, tant pour lui-même que pour le lecteur.

\section{INDEX}

Keywords: disintegration, randomness, cancer, writing, structure, non-structure, experimental, integration, Johnson B.S.

Mots-clés: désintégration, aléatoire, cancer, écriture, structure, non-structure, expérimental, intégration, Johnson B.S.

\section{AUTHOR}

\section{BEN WINSWORTH}

MCF/Senior Lecturer in English Literature and Popular Culture at the University of Orléans. Currently teaching classes on $19^{\text {th }}$ and $20^{\text {th }}$ century literature; the history/analysis of pop/rock in the UK; and an introduction to the study of youth subcultures. Recent publications include: 'Psychic liberation in Sgt Pepper's Lonely Heart's Club Band' in Preserving the Sixties: Britain and the Decade of Protest, edited by Trevor Harris and Monia O'Brien Castro (Palgrave Macmillan, 2014); 'Mod Cons: Back to the Future with the Jam' in Mad Dogs and Englishness: Popular Music and English Identities, edited by Lee Brook, Mark Donnelly and Richard Mills (Bloomsbury, 2017); and "Who (the Fuck) Are You': Out with the In-Crowd in Quadrophenia' in Quadrophenia and Mod(ern) Culture, edited by Pamela Thurschwell (Palgrave Macmillan, 2018). Contact: ben.winsworth [at] univorleans.fr 